\title{
Do Transition Countries Converge towards the European Union?
}

\author{
Dzenita Siljak \\ International University of Sarajevo \\ Hrasnicka cesta 15, \\ Sarajevo 71210, Bosnia and Herzegovina \\ E-mail: dzsiljak@ius.edu.ba \\ Sándor Gyula Nagy \\ Corvinus University of Budapest \\ Bérc utca 13-15, \\ Budapest $\mathrm{H}-1016$, Hungary \\ E-mail: sandorgyula.nagy@ifat.hu
}

Abstract: The aim of this paper is to analyze if the Western Balkan and Eastern Partnership countries converge towards the twenty-eight members of the European Union. The relationships between the selected macroeconomic variables and per capita GDP growth rate are econometrically tested to support this research. The analyzed period is 2004-2017, with two sub-periods: 2004-2008 and 2009-2013. The subdivision is made to test whether the recent financial crisis affected the absolute and conditional convergence process in the analyzed group of countries. The empirical findings support the economic convergence hypothesis. The results show that the recent financial crisis negatively affected the absolute and conditional convergence process, when economic variables are included in the analysis. The negative effects of the crisis on conditional convergence with economic and socio-political variables are not identified. The poorer countries in the analyzed group should do more to attract investment and open their economies, as gross fixed capital formation and economic openness have a positive impact on per capita growth, and keep low inflation or stabilize it, while general government debt and unemployment should be decreased in the examined sample of countries.

Keywords: beta convergence, Eastern Partnership, European Union, transition, Western Balkans 
In this paper, we analyze the real economic convergence process of the Western Balkan countries Albania, Bosnia and Herzegovina, North Macedonia, Kosovo', Montenegro and Serbia; the Eastern Partnership countries Armenia, Azerbaijan, Belarus, Georgia, Moldova and Ukraine; and the twenty-eight Member States of the European Union. The analysis is focused on two types of beta convergenceabsolute (unconditional) and conditional convergence in the period 2004-2017 and two sub-periods of 2004-2008 and 2009-2013.

The Western Balkan and Eastern Partnership countries are transition countries, which are going through the transformation process from centrally planned to market economies. Transition started with the fall of the Berlin Wall in 1989, collapse of communism and the dissolution of Yugoslavia, the Union of Soviet Socialist Republics (USSR) and Czechoslovakia. More than twenty countries gained independence in the 1990s, and for most of them, EU membership was the ultimate goal.

Some characteristics of the centrally planned economic system are limited trade and investment, state ownership of the economy, artificially low inflation and unemployment, and a one-party (Communist Party) monopoly. Transition countries have been following the path of Central and Eastern European (CEE) countries that joined the European Union (EU) in 2004, 2007 and 2013. While they are in the transition process, the countries must fulfill various economic, political and institutional criteria, the Copenhagen criteria (1993), in order to successfully transform the economies. The gist of the criteria fulfillment is that the countries are able to cope with the challenges of being EU Member States. The EU provides pre-accession funds, and once the countries join the Union, they have access to the cohesion funds. The transition process ends when a country joins the EU.

The EU approach to the enlargement has been justified. The CEE countries went through the transition process successfully; they transformed their economies and have been functioning in the EU market. Five former communist countries (Estonia, Latvia, Lithuania, the Slovak Republic and Slovenia) adopted the euro as their currency in the period 2007-2015, together with Cyprus and Malta. As a result of the gradual transition process, the countries of the European Union converge; the average per capita GDP in the EU-13 increased from $48.3 \%$ of the EU-15 average in 2004 to $60.9 \%$ in 2017. Convergence occurs when poor countries grow faster than rich countries. However, the experience of the

1 This designation is without prejudice to positions on status, and is in line with UNSCR 1244/1999 and the ICJ Opinion on the Kosovo declaration of independence (European Commission, 2015). 
European Union shows that convergence does not have to be limited only to a quantitative category; it can be a qualitative one as well. In the EU, convergence is also assimilation of countries.

The Western Balkan countries have made progress, but they will not become EU members any time soon. The countries are candidates (Albania, North Macedonia, Montenegro and Serbia) or potential candidates (Bosnia and Herzegovina and Kosovo) for EU membership. All countries have signed the Stabilization and Association Agreement (SAA). Kosovo is the only country that has not implemented a visa-free regime with the EU.

While the Western Balkan countries have official relations with the European Union, the Eastern Partnership was launched as a specific dimension of the European Neighborhood Policy (ENP) in 2009, but it is not an EU accession process. Its aim is to build a common area of shared democracy, prosperity, stability and increased cooperation (EEAS, 2017).

\section{Table 1. Analyzed groups of countries}

\begin{tabular}{|c|c|}
\hline Group & Countries \\
\hline EU-15 & $\begin{array}{c}\text { Austria, Belgium, Denmark, Finland, France, } \\
\text { Greece, Germany, Ireland, Italy, Luxembourg, the } \\
\text { Netherlands, Portugal, Spain, Sweden, the United } \\
\text { Kingdom }\end{array}$ \\
\hline EU-13 & $\begin{array}{c}\text { Bulgaria, Croatia, Cyprus, Czech Republic, Estonia, } \\
\text { Hungary, Latvia, Lithuania, Malta, Poland, Romania, } \\
\text { Slovakia, Slovenia }\end{array}$ \\
\hline $\begin{array}{l}\text { Central and Eastern } \\
\text { Europe (CEE) }\end{array}$ & $\begin{array}{c}\text { Bulgaria, Croatia, Czech Republic, Estonia, } \\
\text { Hungary, Latvia, Lithuania, Poland, Romania, } \\
\text { Slovakia, Slovenia }\end{array}$ \\
\hline Western Balkans & $\begin{array}{l}\text { Albania, Bosnia and Herzegovina, Kosovo, } \\
\text { Montenegro, North Macedonia, Serbia }\end{array}$ \\
\hline Eastern Partnership & $\begin{array}{c}\text { Armenia, Azerbaijan, Belarus, Georgia, Moldova, } \\
\text { Ukraine }\end{array}$ \\
\hline
\end{tabular}

The main objective of this research is to analyze if transition countries converge towards the EU Member States. Other objectives include: to identify clusters among the analyzed countries and their convergence patterns, and to analyze the determinants of per capita growth.

We test three research hypotheses. The first hypothesis is that the absolute convergence process of the analyzed countries in the pre-crisis period is faster, 
compared to the crisis period. The second hypothesis is that the recent financial crisis had a negative effect on conditional convergence, when economic variables are included in the analysis. The third hypothesis is that the crisis had a negative effect on conditional convergence, when economic and socio-political variables are included in the analysis.

The literature review on convergence is presented in Section 1, followed by Methodology and Data in Section 2. The empirical findings on absolute and conditional convergence are presented and discussed in Section 3. Section 4 provides conclusion and recommendations for the analyzed groups of countries.

\section{Literature review}

Convergence was popularized by Barro and Sala-i-Martin (1992). Based on the Solow neoclassical growth model (1956), they analyze and confirm convergence of $2 \%$ per year in the U.S. states between 1840 and 1988 .

Matkowski and Prochniak (2004) confirm convergence among the eight CEE countries that joined the European Union in 2004. Borys, Polgár, and Zlate (2008) show that the main drivers of convergence of five Western Balkan countries towards ten CEE countries in the period 1993-2005 have been total factor productivity growth and capital deepening, whereas labor has contributed only marginally to economic growth. El ouardighi and Somun-Kapetanovic (2009) analyze the convergence process of five Western Balkan countries towards the EU-27 in the period 1989-2008, concluding that the countries converge in the entire period, but there are differences in the convergence patterns across subperiods. Acharya, Vojinović and Próchniak (2009) confirm convergence among the ten new Member States of the European Union in the period 1992-2006. However, the income gap remained substantial. Szeles and Marinescu (2010) show that the ten CEE countries that joined the EU in 2004 and 2007 converge, in both absolute and conditional terms.

Grzelak and Kujaczynska (2013) find convergence in the EU-27 in the period 2001-2010. The new Member States develop faster, due to improved productivity of production factors, a relatively intensive investment capacity and homogeneity of the group. Sikić (2013) investigates absolute converge of the countries that joined the EU in 2004 in the period 1997-2012, and includes the pre-crisis and crisis sub-periods. The results show that the countries formed a homogeneous convergence club during the entire analyzed period. However, the 
convergence rate and homogeneity of the club diminished in the crisis period. Tsanana, Katrakilidis, and Pantelidis (2013) investigate the issue of catching up between the Balkan countries and the EU-15 between 1989 and 2009. The results show that the income gap relative to the EU-15 remained significant.

Kulhánek (2014) confirms convergence in the European Union in the period 1995-2012, but the convergence rate of the Central European countries towards the EU-15 is lower than the rate of the EU-13 group. Benczes and SzentIvanyi (2015) investigate convergence in the EU (Croatia and Luxembourg are excluded from the analysis) between 2004 and 2014. The authors show that the countries converge and form two clusters; the new and the old Member States. Colak (2015) analyzes if the CEE and SEE countries converge towards the EU15 Member States between 1993 and 2012. The results show a strong tendency of convergence for both groups.

Głodowska (2015) confirms the existence of convergence in the EU countries between 2000 and 2013 on both regional and country level, but the process is faster in the case of countries. Bićanić, Deskar-Škrbić and Zrnc (2016) investigate the convergence process in Yugoslavia successor states and conclude that there was no beta convergence in Yugoslavia, but after the countries declared independence, convergence developed. Benešová, Dlubalová, Rumánková and Laputkova (2017) find convergence in the post-Soviet countries (except the Baltic States) in the period 1995-2016. Grela et al. (2017) confirm that the CEE and other NMS countries converge towards more developed EU countries in absolute terms in the period 1997-2014.

Alcidi, Núñez Ferrer, Di Salvo, Pilati, and Musmeci (2018) confirm that poorer Member States and regions in the European Union converge towards a higher level of per capita GDP between 2000 and 2015. Pipień and Roszkowska (2018) analyze convergence for two groups of post-communist countries: CEE and CIS. The results show the presence of homogeneity in the CEE group, while the CIS countries lack similar convergence patterns among them. Stanišić, Makojević, and Curčić (2018) confirm the existence of convergence of the CEE countries towards the EU-15, but convergence is not found in the case of the Western Balkan countries. Alcidi (2019) finds that the CEE countries had the highest speed of convergence towards the EU average in the period 2000-2015 and that Estonia, Latvia, Lithuania, and Romania registered the best performance. 


\section{Methodology and data}

Convergence occurs when there is a negative relationship between the initial per capita GDP and the per capita GDP growth rate-i.e. when countries with lower per capita GDP achieve higher per capita GDP growth rates. Divergence occurs if the relationship is positive. The analyzed period in this research is 2004-2017, with two sub-periods; the period before the recent financial crisis 2004-2008 and the crisis period 2009-2013.

According to the approach presented by Sala-i-Martin's (1996), we analyze the process of absolute and conditional convergence of transition countries towards the EU Member States using ordinary least square (OLS) regression based on cross-sectional data.

Beta convergence can be absolute (unconditional) and conditional. When it is assumed that countries do not differ in their structures, they converge towards the same steady state and convergence is absolute. However, if countries have different structures, they converge towards different steady state and convergence is conditional.

The $\beta$ coefficient, which captures the speed at which a country converges towards the steady state during one year, is obtained through a regression analysis. The absolute convergence model (Equation 1) includes one dependent and one independent variable; the dependent variable is the average per capita GDP growth rate for the analyzed period, while the independent variable is per capita GDP in purchasing power terms (PPP) at the beginning of the time period, computed in natural logarithm. In order to test absolute and conditional convergence, we estimate the following linear-log model:

$$
\Upsilon_{\mathrm{i} .0, \mathrm{~T}}=\alpha_{\mathrm{i}}+\beta \log \left(\mathrm{Y}_{\mathrm{i}, 0}\right)+\varepsilon_{\mathrm{i}}
$$

The conditional convergence models (Equations 2 and 3) represent the absolute convergence model (1) augmented with various economic, social, political or institutional variables. In this analysis, we include three economic variables; economic openness, gross fixed capital formation and the inflation rate, and three socio-political variables; general government debt, the population growth rate and the unemployment rate.

$$
\Upsilon_{\mathrm{i} .0, \mathrm{~T}}=\alpha_{\mathrm{i}}+\beta_{1} \log \left(\mathrm{Y}_{\mathrm{i}, 0}\right)+\beta_{2} \text { EconOp }_{\mathrm{i} .0, \mathrm{~T}}+\beta_{3} \operatorname{Inf}_{\mathrm{i} .0, \mathrm{~T}}+\beta_{4} \mathrm{GFCF}_{\mathrm{i} 0, \mathrm{~T}}+\varepsilon_{\mathrm{i}} \quad\{2\}
$$




$$
\begin{aligned}
\Upsilon_{\mathrm{i} .0, \mathrm{~T}}=\alpha_{\mathrm{i}}+\beta_{1} \log \left(\mathrm{Y}_{\mathrm{i}, 0}\right)+ & \beta_{2} \text { EconOp }_{\mathrm{i} .0, \mathrm{~T}}+\beta_{3} \operatorname{Inf}_{\mathrm{i} .0, \mathrm{~T}}+\beta_{4} \mathrm{GFCF}_{\mathrm{i} .0, \mathrm{~T}}+\beta_{5} \text { Debt }_{\mathrm{i} 0, \mathrm{~T}}+ \\
& \beta_{6} \text { Pop }_{\mathrm{i} 0, \mathrm{~T}}+\beta_{7} \text { Unemp }_{\mathrm{i} .0, \mathrm{~T}}+\varepsilon_{\mathrm{i}}
\end{aligned}
$$

where :

$\beta$ is the convergence coefficient; ' $\Upsilon_{i ., T}$ is the average annual growth rate of per capita GDP for country $i$; $Y_{i, 0}$ is per capita GDP at PPP for country $i$ at the beginning of the time interval ${ }_{0} ; \alpha_{i}$ is a constant; $\varepsilon_{i}$ is the stochastic error of the equation; $T$ is the end of the time interval; EconOp is the economic openness rate; Inf is the inflation rate; GFCF is gross fixed capital formation; Debt is general government debt; Pop is the population growth rate; and Unemp is the unemployment rate. It is expected that economic openness and gross fixed capital formation will have a positive impact on per capita GDP growth rate, while the other variables should have a negative impact.

We test if the analyzed countries converge in the period 2004-2017 and two sub-periods: the pre-crisis period 2004-2008 and the crisis period 2009-2013. The two sub-periods are included so that we are able to test whether the recent financial crisis had a negative effect on the convergence process. The five-year sub-periods are used because Islam (1995) suggests that an analyzed period should not be shorter than five years. Shorter periods are feasible, but short-term disturbances may appear larger in brief intervals.

In this analysis, we use cross-sectional linear regression to estimate the $\beta$ coefficient; i.e. we use average rates for a given period. The cross-sectional data is used because it is free of the distortions caused by business cycles as well as various demand-side and supply-side random shocks, both internal and external, that deviate the economy from a path towards the steady state (Acharya et al., 2009, p. 127).

In order to investigate relevant model diagnostics, we conduct three tests in all estimated models; the Breusch-Pagan test, which tests the null hypothesis that the variance of the residuals is constant, the test on whether there is multicollinearity among the variables, using the variance inflation factor (VIF), and the Ramsey RESET test, which test the null hypothesis that a model has no omitted variables.

This research is based on annual data. Table 2 presents the descriptive statistics of the variables used to estimate absolute and conditional convergence models in the period 2004-2017. The data set includes forty countries. 
We follow the literature on convergence of transition and EU countries (e.g., Yin, Zestos \& Michelis, 2003; Rapacki \& Prochniak, 2009; Acharya et al., 2009; Szeles \& Marinescu, 2010; Dobrinsky \& Havlik, 2014; Borys et al., 2015). The included macroeconomic variables are generally used in macroeconomic modeling in the sample of current and former transition countries, because they represent some of the characteristics of the transition process. It is important to investigate their impact on the convergence process, because the empirical results can show what promotes per capita growth and on which aspects transition countries should focus their policies.

Table 2. Descriptive statistics

\begin{tabular}{|c|c|c|c|c|c|c|}
\hline Variables & Description & Mean & Median & $\begin{array}{c}\text { Standard } \\
\text { Deviation }\end{array}$ & $\begin{array}{c}\text { Minimum } \\
\text { Value }\end{array}$ & $\begin{array}{c}\text { Maximum } \\
\text { Value }\end{array}$ \\
\hline $\begin{array}{c}\text { Per capita } \\
\text { GDP growth }\end{array}$ & $\begin{array}{c}\text { Annual percentage } \\
\text { growth rate of GDP per } \\
\text { capita based on constant } \\
\text { local currency }\end{array}$ & 2.58 & 2.57 & 1.95 & -0.87 & 7.84 \\
\hline $\begin{array}{c}\text { Log (initial per } \\
\text { capita GDP) }\end{array}$ & $\begin{array}{c}\text { Natural logarithm of } \\
\text { per capita GDP at the } \\
\text { beginning of the analyzed } \\
\text { period }\end{array}$ & 9.61 & 9.66 & 0.78 & 7.88 & 11.07 \\
\hline $\begin{array}{c}\text { Economic } \\
\text { openness }\end{array}$ & $\begin{array}{c}\text { A sum of exports and } \\
\text { imports divided by GDP }\end{array}$ & 112.79 & 99.06 & 57.11 & 53.85 & 344.73 \\
\hline $\begin{array}{c}\text { Inflation rate } \\
\text { Measured by the } \\
\text { Consumer Prices }\end{array}$ & 3.41 & 1.99 & 3.50 & 1.06 & 18.55 \\
\hline $\begin{array}{c}\text { Gross fixed } \\
\text { capital } \\
\text { formation }\end{array}$ & $\begin{array}{c}\text { Measured as a } \\
\text { percentage of GDP }\end{array}$ & 22.77 & 22.71 & 3.39 & 16.37 & 31.54 \\
\hline $\begin{array}{c}\text { General } \\
\text { government } \\
\text { debt }\end{array}$ & $\begin{array}{c}\text { The government debt to } \\
\text { GDP ratio }\end{array}$ & 52.23 & 48.14 & 29.17 & 6.27 & 144.13 \\
\hline $\begin{array}{c}\text { Unemployment } \\
\text { rate }\end{array}$ & $\begin{array}{c}\text { A percentage of total } \\
\text { labor force }\end{array}$ & 11.30 & 8.94 & 7.55 & 0.73 & 38.72 \\
\hline $\begin{array}{c}\text { Unemployment } \\
\text { rate (Belarus } \\
\text { excluded from } \\
\text { the analysis) }\end{array}$ & $\begin{array}{c}\text { A percentage of total } \\
\text { labor force }\end{array}$ & 11.57 & 9.03 & 7.45 & 5.02 & 38.72 \\
\hline $\begin{array}{c}\text { Population } \\
\text { growth }\end{array}$ & $\begin{array}{c}\text { The annual growth rate of } \\
\text { a population }\end{array}$ & 0.14 & 0.10 & 0.71 & -1.35 & 2.02 \\
\hline
\end{tabular}

Source: Authors' own calculations based on Eurostat, World Bank and World Economic Outlook data 
The Eurostat, World Bank, and World Outlook (WEO) data sets are the main source of data for this analysis. Data for growth of per capita GDP, per capita GDP (in PPP), economic openness, gross fixed capital formation, the unemployment rate, and the population growth rate are obtained from the World Bank's database. Data for general government debt, as a percentage of GDP, are derived from Eurostat for the EU Member States, and from the World Economic Outlook database for the non-EU countries. The inflation rates for Bosnia and Herzegovina and Kosovo are also obtained from the WEO database.

\section{Results and discussion}

We analyze if the Western Balkan and Eastern Partnership countries converge towards the EU Member States in the period 2004-2017. In order to test if the recent financial crisis had a negative impact on the convergence process, we include two sub-periods in the analysis: the pre-crisis period 2004-2008 and the crisis period 2009-2013. We estimate twelve convergence models: three absolute convergence models (Models 1-3) and nine conditional convergence models (Models 4-12).

Table 3 presents the regression results for absolute convergence in the analyzed periods.

Table 3. Absolute convergence of transition countries towards the EU Member States

\begin{tabular}{|c|c|c|c|c|}
\hline & $\begin{array}{c}\text { Model 1 } \\
\text { 2004-2017 }\end{array}$ & $\begin{array}{c}\text { Model 2 } \\
\text { 2004-2008 }\end{array}$ & $\begin{array}{c}\text { Model 2' } \\
\text { 2004-2008 }\end{array}$ & $\begin{array}{c}\text { Model 3 } \\
\text { 2009-2013 }\end{array}$ \\
\hline & $\begin{array}{c}\beta \\
(\mathrm{t})\end{array}$ & $\begin{array}{c}\beta \\
(\mathrm{t})\end{array}$ & $\begin{array}{c}\beta \\
(\mathrm{t})\end{array}$ & $\begin{array}{c}\beta \\
(\mathrm{t})\end{array}$ \\
\hline $\begin{array}{c}\text { Log of initial per } \\
\text { capita GDP at PPP }\end{array}$ & $\begin{array}{c}-1.90^{* * *} \\
(-7.29)\end{array}$ & $\begin{array}{c}-3.52^{* * *} \\
(-6.39)\end{array}$ & $\begin{array}{c}-3.52^{* * *} \\
(-5.00)\end{array}$ & $\begin{array}{c}-1.79^{* * *} \\
(-4.61)\end{array}$ \\
\hline $\begin{array}{c}\text { Number of } \\
\text { observations }\end{array}$ & 40 & 40 & 40 & 40 \\
\hline $\begin{array}{c}\text { Number of panel } \\
\text { observations }\end{array}$ & 560 & 200 & 200 & 200 \\
\hline $\begin{array}{c}F \text { statistics }(p \text {-value) } \\
\text { F }\end{array}$ & 53.21 & 40.89 & 24.95 & 21.27 \\
$(0.0000)$ & $(0.0000)$ & $(0.0000)$ & $(0.0000)$ \\
\hline$R^{2}$ & 0.5834 & 0.5183 & 0.5183 & 0.3588 \\
\hline
\end{tabular}

Significant codes: ${ }^{* * *} p<0.01,{ }^{* *} p<0.05,{ }^{*} p<0.1$

Source: Authors' own calculations based on World Bank data 
The regression results show that the countries converge in every analyzed period. The $\beta$ coefficient for the period 2004-2017 is negative, -1.90 , and highly significant at $p=0.0000$, which means that, if the countries do not differ in their structures, they converge towards the same steady state at the rate of $1.90 \%$ per year. The convergence rate in the pre-crisis period is $3.52 \%$, and this is the only rate that exceeds the reference value of $2 \%$ from the Barro and Sala-i-Martin (1992) findings. The rate during the crisis period decreases to $1.79 \%$. Comparing the convergence rates during the pre-crisis and crisis period, we conclude that the convergence process slowed down during the recent financial crisis. Therefore, we do not have enough evidence to reject the first research hypothesis.

We do not find multicollinearity in the estimated models and the models have a proper functional form, but the problem of heteroskedasticity is detected in Model 2. When we estimate regression with a heteroskedasticity robust standard error (Model 2'), the issue of heteroskedasticity is corrected and the $\beta$ coefficient remains unchanged.

Figure 1 plots per capita GDP at the beginning of the time period (X-axis) and the average per capita GDP growth rate in the period 2004-2017. The Figure indicates convergence among the countries, as the regression line has a downward slope and shows a negative relationship between the variables.

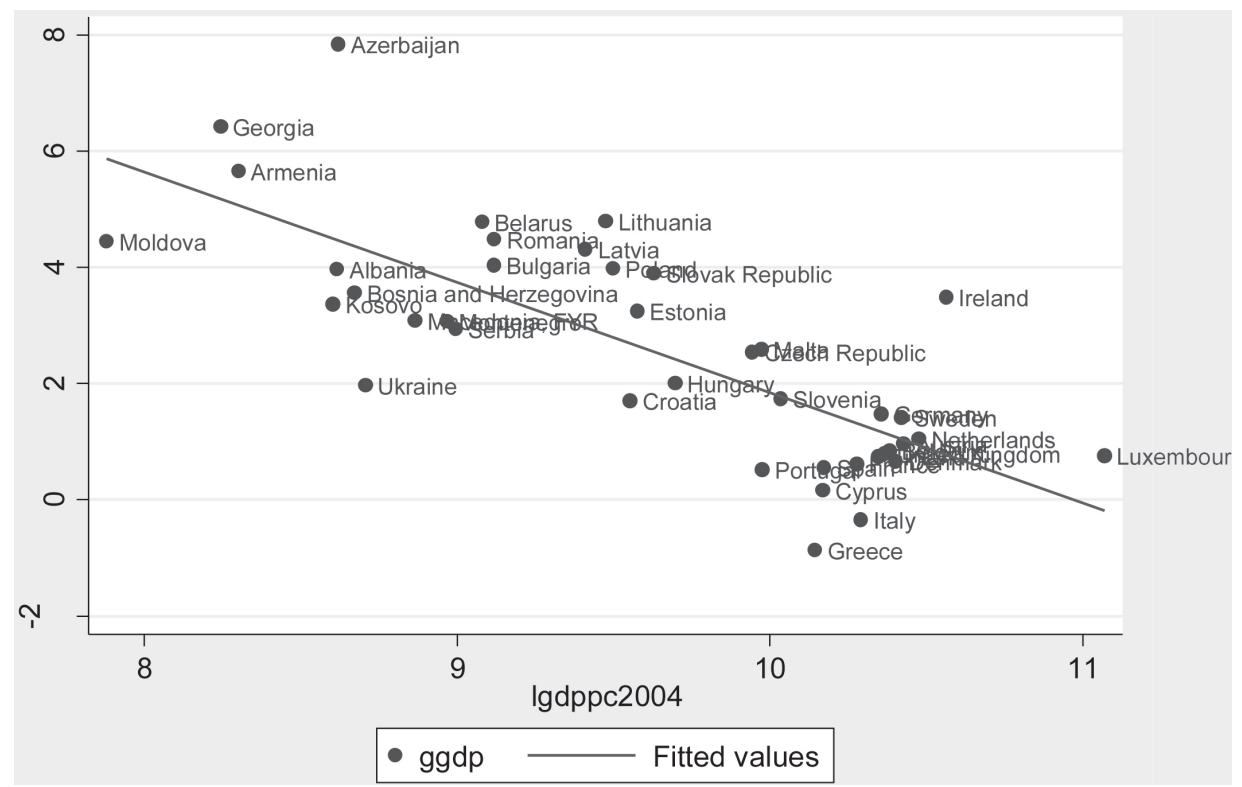

Figure 1. Absolute convergence in the analyzed countries in the period 2004-2017 Source: Authors' own calculations based on World Bank data 
The Figure shows that the Western Balkan countries form a cluster and are homogeneous. Their average per capita growth rate in the analyzed period is $3.3 \%$. The Eastern Partnership countries are very heterogeneous. Armenia, Azerbaijan, Georgia and Moldova are positioned in the upper left corner in the Figure, which indicates that they have the lowest initial per capita GDP, but the highest growth rates $(5.7 \%, 7.8 \%, 6.4 \%$ and $4.5 \%$, respectively). Ukraine's growth rate $(2 \%)$ is similar to the rate of the cluster formed by Croatia, the Czech Republic, Hungary, Malta, and Slovenia (2.1\%). However, Ukraine's per capita GDP in 2004 was only $31.7 \%$ of the countries' average per capita GDP. Belarus converges with the only former USSR countries that have joined the European Union-Estonia, Latvia and Lithuania. Together with Bulgaria, Poland, Romania and the Slovak Republic, these countries form a cluster that grew at an average per capita rate of $4.2 \%$ in the analyzed period. Together with Cyprus, the EU-15 Member States are positioned in the lower right corner, which means that the countries with the highest per capita GDP in the group achieved the lowest growth rates. Ireland is an outlier and does not belong to this cluster, because the average per capita growth rate in the group was $0.8 \%$ in the analyzed period, but Ireland's rate was 3.5\%.

Between 2004 and 2017, the Western Balkan countries' average per capita GDP increased from $26.4 \%$ to $34.4 \%$ of the EU average, while in the Eastern Partnership countries the ratio increased from $20.4 \%$ to $28.8 \%$.

\subsection{Conditional convergence}

We estimate nine conditional convergence models: three models with economic variables (Models 4-6) and six models with economic and socio-political variables (Models 7-12). The empirical results can serve as a recommendation for countries when they are deciding which policies should be pursued in order to increase per capita GDP growth rates.

Table 4 presents the regression results for conditional convergence, when economic variables are included in the models.

The results show that, when economic variables are included in the models, the transition countries converge towards the EU-28 in every analyzed period. In the period before the crisis, the convergence rate is higher than in other periods, so we conclude that the recent financial crisis had a negative impact on the conditional convergence process, when economic variables are included in the analysis, and slowed it down. Therefore, we cannot reject the second research hypothesis. 
Table 4. Conditional convergence in the analyzed group of countries, when economic variables are included in the analysis

\begin{tabular}{|c|c|c|c|c|}
\hline & $\begin{array}{c}\text { Model } 4 \\
2004-2017\end{array}$ & $\begin{array}{c}\text { Model } 5 \\
\text { 2004-2008 }\end{array}$ & $\begin{array}{c}\text { Model 5' } \\
\text { 2004-2008 }\end{array}$ & $\begin{array}{c}\text { Model } 6 \\
2009-2013 \\
\end{array}$ \\
\hline & $\begin{array}{l}\beta \\
(\mathrm{t})\end{array}$ & $\begin{array}{l}\beta \\
(\mathrm{t})\end{array}$ & $\begin{array}{l}\beta \\
(\mathrm{t})\end{array}$ & $\begin{array}{l}\beta \\
(\mathrm{t})\end{array}$ \\
\hline $\begin{array}{l}\text { Log of initial per } \\
\text { capita GDP at PPP }\end{array}$ & $\begin{array}{l}-1.71^{* * *} \\
(-5.76)\end{array}$ & $\begin{array}{l}-1.80^{* *} \\
(-2.65)\end{array}$ & $\begin{array}{l}-1.80^{* *} \\
(-2.64)\end{array}$ & $\begin{array}{l}-1.72^{* * \star} \\
(-4.20)\end{array}$ \\
\hline $\begin{array}{c}\text { Economic openness } \\
(\%)\end{array}$ & $\begin{array}{l}0.01^{* *} \\
(2.45)\end{array}$ & $\begin{array}{c}0.01 \\
(0.66)\end{array}$ & $\begin{array}{l}0.01 \\
(0.92)\end{array}$ & $\begin{array}{l}0.01^{*} \\
(1.88)\end{array}$ \\
\hline $\begin{array}{l}\text { Gross fixed capital } \\
\text { formation }(\% \text { of GDP) }\end{array}$ & $\begin{array}{l}0.18^{* * *} \\
(2.96)\end{array}$ & $\begin{array}{l}0.26^{* *} \\
(2.73) \\
\end{array}$ & $\begin{array}{l}0.26^{* *} \\
(2.28) \\
\end{array}$ & $\begin{array}{c}0.13 \\
(1.54) \\
\end{array}$ \\
\hline $\begin{array}{c}\text { Inflation rate (annual } \\
\%)\end{array}$ & $\begin{array}{c}-0.01 \\
(-0.19)\end{array}$ & $\begin{array}{l}0.37^{* \star} \\
(2.57)\end{array}$ & $\begin{array}{l}0.37^{*} \\
(1.87)\end{array}$ & $\begin{array}{c}0.01 \\
(0.12)\end{array}$ \\
\hline $\begin{array}{l}\text { Number of } \\
\text { observations }\end{array}$ & 40 & 40 & 40 & 40 \\
\hline $\begin{array}{l}\text { Number of panel } \\
\text { observations }\end{array}$ & 560 & 200 & 200 & 200 \\
\hline$F$ statistics ( $p$-value) & $\begin{array}{c}21.96 \\
(0.0000)\end{array}$ & $\begin{array}{c}18.97 \\
(0.0000)\end{array}$ & $\begin{array}{c}7.71 \\
(0.0001)\end{array}$ & $7.88(0.0001)$ \\
\hline $\mathrm{R}^{2}$ & 0.7151 & 0.6844 & 0.6844 & 0.4739 \\
\hline
\end{tabular}

Significant codes: ${ }^{* *} p<0.01,{ }^{* *} p<0.05,{ }^{*} p<0.1$

Source: Authors' own calculations based on World Bank and World Economic Outlook data

The issue of heteroskedasticity is detected in the pre-crisis model. When regression with a heteroskedasticity robust standard error is estimated (Model 5'), the results do not change.

Tables 5 and 6 present the regression results for conditional convergence models, when economic and socio-political variables are included. Models 7-9 include Belarus in the analysis, while in Models 10-12 the country is excluded as an outlier.

Belarus is excluded from Models 10-12, because the country's official unemployment rate in the analyzed period is $0.7 \%$. There are no data on the country's real unemployment rate, but it is estimated that the rate ranges between $5 \%$ and $10 \%$, or even higher. Unemployed people in Belarus do not register with the employment agencies, because if they do, they will have to participate in public work programs, which include seasonal agricultural work or street sweeping and the payment is very low, just like the level of unemployment benefits (Preiherman, 2012). 
Table 5. Conditional convergence in the analyzed group of countries, when economic and socio-political variables are included in the analysis

\begin{tabular}{|c|c|c|c|c|c|}
\hline & $\begin{array}{c}\text { Model } 7 \\
2004- \\
2017\end{array}$ & $\begin{array}{c}\text { Model 7' } \\
2004- \\
2017\end{array}$ & $\begin{array}{l}\text { Model } 8 \\
2004- \\
2008\end{array}$ & $\begin{array}{l}\text { Model 8' } \\
2004- \\
2008\end{array}$ & $\begin{array}{c}\text { Model } 9 \\
2009- \\
2013\end{array}$ \\
\hline & $\begin{array}{c}\beta \\
(\mathrm{t})\end{array}$ & $\begin{array}{c}\beta \\
(t)\end{array}$ & $\begin{array}{l}\beta \\
(t)\end{array}$ & $\begin{array}{l}\beta \\
(\mathrm{t})\end{array}$ & $\begin{array}{l}\beta \\
(\mathrm{t})\end{array}$ \\
\hline $\begin{array}{l}\text { Log of initial per } \\
\text { capita GDP at PPP }\end{array}$ & $\begin{array}{l}-1.86^{* * *} \\
(-4.53)\end{array}$ & $\begin{array}{l}-1.86^{* * *} \\
(-2.79)\end{array}$ & $\begin{array}{l}-1.97 \\
(-1.54)\end{array}$ & $\begin{array}{l}-1.97 \\
(-1.08)\end{array}$ & $\begin{array}{l}-1.41^{* *} \\
(-2.54)\end{array}$ \\
\hline $\begin{array}{c}\text { Economic openness } \\
(\%)\end{array}$ & $\begin{array}{l}0.004 \\
(1.11)\end{array}$ & $\begin{array}{l}0.004 \\
(1.14)\end{array}$ & $\begin{array}{l}0.001 \\
(0.06)\end{array}$ & $\begin{array}{l}0.001 \\
(0.09)\end{array}$ & $\begin{array}{l}0.005 \\
(0.98)\end{array}$ \\
\hline $\begin{array}{c}\text { Gross fixed capital } \\
\text { formation ( } \% \text { of } \\
\text { GDP) }\end{array}$ & $\begin{array}{l}0.12^{*} \\
(1.96)\end{array}$ & $\begin{array}{l}0.12^{*} \\
(1.81)\end{array}$ & $\begin{array}{l}0.19^{*} \\
(1.70)\end{array}$ & $\begin{array}{c}0.19 \\
(1.64)\end{array}$ & $\begin{array}{l}0.08 \\
(0.94)\end{array}$ \\
\hline $\begin{array}{l}\text { Inflation rate (annual } \\
\% \text { ) }\end{array}$ & $\begin{array}{l}-0.08 \\
(-1.23)\end{array}$ & $\begin{array}{l}-0.08 \\
(-1.30)\end{array}$ & $\begin{array}{c}0.27 \\
(1.33)\end{array}$ & $\begin{array}{c}0.27 \\
(1.24)\end{array}$ & $\begin{array}{l}0.002 \\
(0.03)\end{array}$ \\
\hline $\begin{array}{c}\text { General government } \\
\text { debt (\% of GDP) }\end{array}$ & $\begin{array}{l}-0.02^{* *} \\
(-2.26)\end{array}$ & $\begin{array}{l}-0.02^{* * *} \\
(-2.93)\end{array}$ & $\begin{array}{c}-0.03 \\
(-1.69)\end{array}$ & $\begin{array}{l}-0.03^{* * *} \\
(-2.81)\end{array}$ & $\begin{array}{l}-0.02^{*} \\
(-1.92)\end{array}$ \\
\hline $\begin{array}{l}\text { Population growth } \\
\text { (annual \%) }\end{array}$ & $\begin{array}{l}-0.03 \\
(-0.12)\end{array}$ & $\begin{array}{l}-0.03 \\
(-0.06)\end{array}$ & $\begin{array}{l}-0.03 \\
(-0.06)\end{array}$ & $\begin{array}{l}-0.03 \\
(-0.03)\end{array}$ & $\begin{array}{l}-0.15 \\
(-0.39)\end{array}$ \\
\hline $\begin{array}{l}\text { Unemployment rate } \\
\qquad(\text { annual \%) }\end{array}$ & $\begin{array}{l}-0.06^{* *} \\
(-2.07)\end{array}$ & $\begin{array}{l}-0.06 \\
(-1.63)\end{array}$ & $\begin{array}{l}-0.04 \\
(-0.53)\end{array}$ & $\begin{array}{l}-0.04 \\
(-0.48)\end{array}$ & $\begin{array}{l}-0.04 \\
(-1.00)\end{array}$ \\
\hline $\begin{array}{c}\text { Number of } \\
\text { observations }\end{array}$ & 40 & 40 & 40 & 40 & 40 \\
\hline $\begin{array}{c}\text { Number of panel } \\
\text { observations }\end{array}$ & 560 & 560 & 200 & 200 & 200 \\
\hline$F$ statistics ( $p$-value) & $\begin{array}{c}16.03 \\
(0.0000)\end{array}$ & $\begin{array}{c}28.52 \\
(0.0000)\end{array}$ & $\begin{array}{c}11.23 \\
(0.0000)\end{array}$ & $\begin{array}{c}17.26 \\
(0.0000)\end{array}$ & $\begin{array}{c}5.46 \\
(0.0003)\end{array}$ \\
\hline $\mathrm{R}^{2}$ & 0.7781 & 0.7781 & 0.7107 & 0.7107 & 0.5442 \\
\hline
\end{tabular}

Significant codes: ${ }^{* * *} p<0.01,{ }^{* *} p<0.05,{ }^{*} p<0.1$

Source: Authors' own calculations based on World Bank, World Economic Outlook and Eurostat data 
Table 6. Conditional convergence in the analyzed group of countries, when economic and socio-political variables are included in the analysis, excluding Belarus

\begin{tabular}{|c|c|c|c|c|c|}
\hline & $\begin{array}{c}\text { Model } 10 \\
2004- \\
2017\end{array}$ & $\begin{array}{c}\text { Model 10' } \\
2004- \\
2017\end{array}$ & $\begin{array}{c}\text { Model } 11 \\
2004- \\
2008\end{array}$ & $\begin{array}{c}\text { Model 11' } \\
2004- \\
2008\end{array}$ & $\begin{array}{c}\text { Model } 12 \\
2009- \\
2013\end{array}$ \\
\hline & $\begin{array}{l}\beta \\
(\mathrm{t})\end{array}$ & $\begin{array}{l}\beta \\
(\mathrm{t})\end{array}$ & $\begin{array}{l}\beta \\
(\mathrm{t})\end{array}$ & $\begin{array}{c}\beta \\
(\mathrm{t})\end{array}$ & $\begin{array}{l}\beta \\
(\mathrm{t})\end{array}$ \\
\hline $\begin{array}{l}\text { Log of initial per } \\
\text { capita GDP at PPP }\end{array}$ & $\begin{array}{l}-2.05^{\star \star *} \\
(-4.08)\end{array}$ & $\begin{array}{c}-2.05^{\star * \star} \\
(-2.94)\end{array}$ & $\begin{array}{l}-1.99 \\
(-1.53)\end{array}$ & $\begin{array}{l}-1.99 \\
(-1.12)\end{array}$ & $\begin{array}{c}-1.94^{* * *} \\
(-3.04)\end{array}$ \\
\hline $\begin{array}{c}\text { Economic openness } \\
(\%)\end{array}$ & $\begin{array}{l}0.004 \\
(1.06)\end{array}$ & $\begin{array}{l}0.004 \\
(1.09)\end{array}$ & $\begin{array}{l}0.0005 \\
(0.06)\end{array}$ & $\begin{array}{l}0.0005 \\
(0.09)\end{array}$ & $\begin{array}{l}0.004 \\
(0.81)\end{array}$ \\
\hline $\begin{array}{l}\text { Gross fixed capital } \\
\text { formation ( } \% \text { of GDP) }\end{array}$ & $\begin{array}{c}0.09 \\
(1.27)\end{array}$ & $\begin{array}{c}0.09 \\
(1.25)\end{array}$ & $\begin{array}{c}0.19 \\
(1.67)\end{array}$ & $\begin{array}{c}0.19 \\
(1.64)\end{array}$ & $\begin{array}{c}0.02 \\
(0.24)\end{array}$ \\
\hline $\begin{array}{c}\text { Inflation rate } \\
\text { (annual \%) }\end{array}$ & $\begin{array}{l}-0.14 \\
(-1.28)\end{array}$ & $\begin{array}{l}-0.14 \\
(-1.19)\end{array}$ & $\begin{array}{c}0.25 \\
(1.23)\end{array}$ & $\begin{array}{c}0.25 \\
(1.12)\end{array}$ & $\begin{array}{l}-0.30 \\
(-1.47)\end{array}$ \\
\hline $\begin{array}{l}\text { General government } \\
\text { debt (\% of GDP) }\end{array}$ & $\begin{array}{l}-0.02^{* *} \\
(-2.32)\end{array}$ & $\begin{array}{l}-0.02^{* * *} \\
(-3.06)\end{array}$ & $\begin{array}{l}-0.03 \\
(-1.64)\end{array}$ & $\begin{array}{l}-0.03^{* *} \\
(-2.73)\end{array}$ & $\begin{array}{l}-0.02^{* *} \\
(-2.24)\end{array}$ \\
\hline $\begin{array}{l}\text { Population growth } \\
\text { (annual \%) }\end{array}$ & $\begin{array}{c}-0.01 \\
(-0.02)\end{array}$ & $\begin{array}{l}-0.01 \\
(-0.01)\end{array}$ & $\begin{array}{l}-0.02 \\
(-0.04)\end{array}$ & $\begin{array}{l}-0.02 \\
(-0.02)\end{array}$ & $\begin{array}{l}-0.09 \\
(-0.22)\end{array}$ \\
\hline $\begin{array}{l}\text { Unemployment rate } \\
\text { (annual \%) }\end{array}$ & $\begin{array}{l}-0.07^{* *} \\
(-2.15)\end{array}$ & $\begin{array}{l}-0.07^{*} \\
(-1.78)\end{array}$ & $\begin{array}{l}-0.04 \\
(-0.51)\end{array}$ & $\begin{array}{l}-0.04 \\
(-0.45)\end{array}$ & $\begin{array}{l}-0.05 \\
(-1.34)\end{array}$ \\
\hline $\begin{array}{l}\text { Number of } \\
\text { observations }\end{array}$ & 40 & 40 & 40 & 40 & 40 \\
\hline $\begin{array}{l}\text { Number of panel } \\
\text { observations }\end{array}$ & 560 & 560 & 200 & 200 & 200 \\
\hline$F$ statistics ( $p$-value) & $\begin{array}{c}15.14 \\
(0.0000)\end{array}$ & $\begin{array}{c}29.00 \\
(0.0000)\end{array}$ & $\begin{array}{c}10.07 \\
(0.0000)\end{array}$ & $\begin{array}{c}15.02 \\
(0.0000)\end{array}$ & $\begin{array}{c}5.40 \\
(0.0004)\end{array}$ \\
\hline $\mathrm{R}^{2}$ & 0.7737 & 0.7737 & 0.6946 & 0.6946 & 0.5493 \\
\hline
\end{tabular}

Significant codes: ${ }^{* * *} p<0.01,{ }^{* *} p<0.05,{ }^{*} p<0.1$

Source: Authors' own calculations based on World Bank, World Economic Outlook and Eurostat data

The results for conditional convergence, when economic and socio-political variables are included, are consistent in both cases, when Belarus is included in and excluded from the analysis. The countries converge in the entire and crisis period. In the pre-crisis period, the $\beta$ coefficients are negative but not statistically significant, so the countries do not converge. The recent financial crisis did not negatively impact the conditional convergence process. Therefore, we reject the third research hypothesis. 
Three economic variables - economic openness, the inflation rate and gross fixed capital formation - and three socio-political variables-general government debt, the unemployment rate and the population growth rate-are included in the analysis.

When only economic variables are included in the models, each variable is statistically significant in at least one analyzed period, and they all have positive estimated coefficients. Economic openness has a positive impact on per capita growth in the entire and crisis period; gross fixed capita formation is a determinant of growth in the entire and pre-crisis period, while the inflation rate is a determinant only in the pre-crisis period.

When economic and socio-political variables are included in the models, gross fixed capital formation is the only statistically significant economic variable and it has a positive impact on per capita growth in the entire and pre-crisis period, when Belarus is not excluded as an outlier. General government debt and the unemployment rate have a negative impact on per capita growth in both models-general government debt in the entire and crisis period and the unemployment rate in the entire analyzed period. The population growth rate is the only variable that is not statistically significant in any analyzed period.

Heteroskedasticity is detected in both models for the entire analyzed period and the pre-crisis period. When regressions with heteroskedasticity robust standard errors are estimated (Models 7', 8', 10' and 11'), the conditional convergence rates do not change. The difference occurs in the determinants of growth in the models-gross fixed capital formation, general government debt and the unemployment rate. Gross fixed capital formation and unemployment are determinants of per capita growth in the models when Belarus is included in the analysis, but they are not statistically significant variables in the corrected models. However, general government debt becomes a statistically significant variable when regressions with heteroskedasticity robust standard errors are estimated in Models 8' and 11'.

The Western Balkans and Eastern Partnership countries are going through the transition process from centrally planned to market economies. The process, which started with the fall of the Berlin Wall in 1989, for the CEE countries ended when they joined the European Union in 2004, 2007 and 2013, respectively. ${ }^{2}$ The analyzed macroeconomic variables are included in the convergence

2 The Czech Republic, Estonia, Hungary, Latvia, Lithuania, Poland, Slovakia, Slovenia, together with Cyprus and Malta, joined the EU in 2004, followed by Bulgaria and Romania in 2007, and Croatia in 2013. 
analysis because they represent the aspects countries have to focus on, improve, or stabilize during their transition. The population growth rate is taken from the Solow growth model.

The communist countries were closed economies. State-owned companies did not trade on foreign markets and did not act according to the model of supply and demand, but according to five-year plans. They produced what they were ordered to and were supplied with resources (Berend, 2016). As a consequence, the economic openness of transition countries has been lower, compared to the countries of the European Union. The average economic openness rate in the European Union in the period 2004-2017 was 120.3\%-101.1\% in the Eastern Partnership countries and $89.3 \%$ in the Western Balkans.

In the entire analyzed period, the Eastern Partnership countries had the highest average gross fixed capital formation rate, $25.8 \%-2.1$ percentage points higher than the Western Balkan average and 3.9 percentage points higher than the EU average.

Prices in communism were not influenced by supply and demand. Some of them were artificially low to make them affordable for the population, such as food products, transportation or baby clothes. Others were artificially high (textile, home appliances and other consumer goods), often three to four times above cost of production (Berend, 2016). After the collapse of communism, the countries faced hyperinflation. The highest rate was registered in Ukraine in 1993 - 4734.9\%. The inflation rate started to stabilize between 1994 and 1998. On average, the inflation rate of the Western Balkan and Eastern Partnership countries is higher than the EU rate. One of the reasons is that nineteen EU Member States (five of them are former communist countries ${ }^{3}$ ) share the same currency, the euro. According to the Maastricht criteria, "the criterion on price stability shall mean that a Member State has a price performance that is sustainable and an average rate of inflation, observed over a period of one year before the examination, that does not exceed by more than 1.5 percentage points that of, at most, the three best-performing Member States in terms of price stability" (European Central Bank, 2018, p. 4). In the analyzed period, the average inflation rate in the European Union was 2.2\%, 3\% in the Western Balkans and $9.6 \%$ in the Eastern Partnership countries. ${ }^{4}$

The former communist countries did not inherit high general government debt

3 Slovenia adopted the euro as its currency in 2007, followed by Slovakia in 2009, Estonia in 2011, Latvia in 2013, and Lithuania in 2015.

4 In 2015, Ukraine's inflation rate was $48.7 \%$ 
rates from the previous system. The average rate of the CEE (38.8\%), Western Balkan (37.9\%), and Eastern Partnership (32.5\%) countries was lower than in the EU-15 (73.4\%) between 2004 and 2017. The new Member States that have not adopted the euro as their currency will have to do that at some point. Another Maastricht criterion requires that the ratio of government debt to gross domestic product must not exceed $60 \%$ of the GDP (European Central Bank, 2018), so the countries have to maintain the level of general government debt below the reference value. In 2017, Croatia and Hungary were the only non-eurozone Member States with general government debt higher than the reference value (77.5\% and $73.3 \%$, respectively).

Unemployment was almost nonexistent in the centrally planned system. After the collapse of communism, the unemployment rates jumped and reached double digits in most newly independent countries. The differences between the Member States of the European Union are not noticeable, because the average unemployment rate in the EU-15 was 8.6\% in the period 2004-2017, compared to the rate of $9.4 \%$ in the CEE countries. The average rate in the Western Balkans was $25.3 \%$ and $8.6 \%$ in the Eastern partnership countries. When we exclude Belarus, the average unemployment rate in the group is $10.2 \%$.

One of the greatest determinants of the widening gap between countries has been the difference in population growth rates, because if population grows more quickly than GDP, per capita GDP falls (de la Dehesa, 2008). In the European Union, population grew at an average rate of $0.2 \%$ in the analyzed period, while it decreased at the rate of $0.1 \%$ in both the Western Balkan and Eastern Partnership countries.

\section{Conclusion}

In this paper we investigate the convergence process of the Western Balkan and Eastern Partnership countries towards the twenty-eight Member States of the European Union. The analyzed period is 2004-2017 with two sub-periods: the pre-crisis period 2004-2008 and the crisis period 2009-2013. Two types of beta convergence are analyzed: absolute (unconditional) and conditional convergence.

The empirical results suggest that there is absolute convergence of transition countries towards the EU-28 in every analyzed period. The absolute convergence process was slower during the recent financial crisis, because the convergence 
rate in the period 2009-2013 is lower than the rate in the period 2004-2008. We do not have enough evidence to reject the first research hypothesis.

The regression results for conditional convergence model, when economic variables are included in the analysis, show that the convergence rate in the period 2004-2008 is the highest, indicating that the recent financial crisis had a negative impact on the conditional convergence process in the analyzed group. Therefore, the second research hypothesis is not rejected.

When economic and socio-political variables are included in the models, the highest convergence rates are throughout the entire analyzed period. Even though the $\beta$ coefficients are negative in the pre-crisis period, they are not statistically significant in the estimated models, and we reject the third research hypothesis.

The only selected macroeconomic variable that does not affect per capita growth rate is the population growth rate. The remaining variables are statistically significant in at least one analyzed period. Economic openness, inflation and gross fixed capital formation have a positive impact on per capita growth, while general government debt and the unemployment rate have a negative impact.

According to the empirical results of the study, economic openness, inflation, and gross fixed capital formation promote per capita growth in the analyzed group. The results imply that the countries should open their economies to more investment and trade, which is one of the main aspects and benefits of EU membership, and stabilize inflation, especially in the Eastern Partnership countries. The study also shows that the countries should pursue policies that will decrease unemployment and general government debt. Improvements in these areas could lead to higher per capita growth rates and a faster convergence process.

Dzenita Siljak, $\mathrm{PhD}$ in economics, is assistant professor at the International University of Sarajevo, Bosnia and Herzegovina and associate research fellow at the Institute for Foreign Affairs and Trade in Budapest, Hungary. Her research interests are related to economic growth, European integration, economics of transition countries, and economic modeling.

Sándor Gyula Nagy, PhD in economics, is associate professor at the Corvinus University of Budapest, Hungary and senior research fellow at the Institute for Foreign Affairs and Trade, Budapest, Hungary. His research interests include Latin American and Spanish economies and the process of global, regional, and European integration. 


\section{References}

Acharya, S.; Vojinović, B. \& Próchniak, M. (2009), 'Convergence analysis among the ten European transition economies,' Hitotsubashi Journal of Economics, vol. 50, no. 2, pp. 17-35.

Alcidi, C. (2019), 'Economic integration and income convergence in the EU,' Intereconomics, vol. 54, no. 1, pp. 5-11. https://doi.org/10.1007/s10272-019-0783-6

Alcidi, C.; Núñez Ferrer, J.; Di Salvo, M.; Pilati, M. \& Musmeci, R. (2018), Income Convergence in the EU: A Tale of Two Speeds, CEPS Commentary, 9 January.

Berend, I. T. (2016), An Economic History of Twentieth-Century Europe: Economic Regimes from Laissez-Faire to Globalization, Cambridge: Cambridge University Press. https://doi.org/10.1017/CBO9781316479889

Barro, R. J. \& Sala-i-Martin, X. (1992), 'Convergence,' Journal of Political Economy, vol. 100, no. 2, pp. 223-251. https://doi.org/10.1086/261816

Benczes, I. \& Szent-Ivanyi, B. (2015), 'The European economy in 2014: fragile recovery and convergence,' JCMS: Journal of Common Market Studies, vol. 53, pp. 162-180. https://doi.org/10.1111/jcms.12266

Benešová, I.; Dlubalová, Z.; Rumánková, L. \& Laputkova, A. (2017), 'Economic convergence of the post-Soviet countries,' Paper presented at the 20th International Scientific Conference "Enterprise and Competitive Environment", Brno, March 9-10, 2017.

Bićanić, I.; Deskar-Škrbić, M. \& Zrnc, J. (2016), A Narrative Explanation of Breakpoints and Convergence Patterns in Yugoslavia and its Successor States 1952-2015, The wiiw Balkan Observatory Working Paper, no. 122.

Borys, M. M.; Polgár, É. K. \& Zlate, A. (2008), Real Convergence and the Determinants of Growth in EU Candidate and Potential Candidate Countries-A Panel Data Approach, ECB Occasional Paper, no. 86.

Colak, O. (2015), 'Convergence revisited: case of EU and Eastern Europe,' Regional Science Inquiry, vol. 7, no. 1, pp. 69-81.

de la Dehesa, G. (2008), Winners and Losers in Globalization, Malden, MA: John Wiley \& Sons.

Dobrinsky, R. \& Havlik, P. (2014), Economic Convergence and Structural Change: The Role of Transition and EU Accession, wiiw Research Report, no. 395 (July).

El ouardighi, J. \& Somun-Kapetanovic, R. (2009), 'Convergence and inequality of income: the case of Western Balkan countries,' The European Journal of Comparative Economics, vol. 6, no. 2, pp. 207-226.

European Central Bank (2018), Convergence Report, Frankfurt am Main.

European Commission (2015), Economic Reform Programmes of Albania, The Former 
Yugoslav Republic of Macedonia, Montenegro, Serbia, Turkey, Bosnia and Herzegovina and Kosovo: The Commission's overview and Country assessments, Luxembourg: Publications Office of the European Union.

EEAS (2017), Myths about the Eastern Partnership - Factsheet, 20 November, Brussels: European External Action Service.

Eurostat (2018), Eurostat Database. Retrieved from www.ec.europa.eu/Eurostat [accessed 7 Dec 2018]

Glodowska, A. (2015), 'Beta and sigma convergence within the European Union countries and regions,' in Proceedings of the 6th Global Conference on Managing in Recovering Markets, GCMRM 2015, Maribor, May 18-19, 2015, pp. 233-246.

Grela, M.; Majchrowska, A.; Michałek, T.; Mućk, J.; Stążka-Gawrysiak, A.; Tchorek, G. \& Wagner, M. (2017), Is Central and Eastern Europe Converging towards the EU-15? Narodowy Bank Polski Working Paper, no. 264, Warsaw: Economic Research Department.

Grzelak, A. \& Kujaczyńska, M. (2013), 'Real convergence of the European Union member states - evaluation attempt,' Management, vol. 17, no. 1, pp. 393-404. https://doi.org/10.2478/manment-2013-0028

IMF (2018), World Economic Outlook Database, International Monetary Fund. Retrieved from www.imf.org [accessed 7 Dec 2018]

Islam, N. (1995), 'Growth empirics: a panel data approach,' The Quarterly Journal of Economics, vol. 110, no. 4, pp. 1127-1170. https://doi.org/10.2307/2946651

Kulhánek, L. (2014), 'Debt crisis and convergence in the European Union,' in International Conference on European Integration, Ostrava: VŠB-TU, Ostrava: Faculty of Economics, pp. 401-409.

Matkowski, Z. \& Próchniak, M. (2004), Economic Convergence in the EU Accession Countries: Composite Indicators of Business Activity for Macroeconomic Analysis, The RIED Papers and Proceedings, vol. 74, pp. 405-425.

Pipień, M. \& Roszkowska, S. (2019), 'The heterogeneity of convergence in transition countries,' Post-Communist Economies, vol. 31, no. 1, pp. 75-105. https://doi.org/10.1080/14631377.2018.1443245

Preiherman, Y. (2012), 'The lie of full employment,' Belarus Digest. Retrieved from https://belarusdigest.com/story/the-lie-of-full-employment/ [accessed 17 Jun 2018]

Rapacki, R. \& Próchniak, M. (2009), 'Real beta and sigma convergence in 27 transition countries, 1990-2005,' Post-Communist Economies, vol. 21, no. 3, pp. 307-326. https://doi.org/10.1080/14631370903090616

Sala-i-Martin, X. X. (1996), 'The classical approach to the convergence analysis,' The Economic Journal, vol. 106, no. 437, pp. 1019-1036. https://doi.org/10.2307/2235375 
Šikić, L. (2013), 'Long term economic convergence among ten new EU member states in the light of the economic crisis,' Financial Theory and Practice, vol. 37, no. 4, pp. 361-381. https://doi.org/10.3326/fintp.37.4.2

Solow, R. M. (1956), 'A contribution to the theory of economic growth,' Quarterly Journal of Economics, vol. 70, pp. 65-94. https://doi.org/10.2307/1884513

Stanišić, N.; Makojević, N. \& Tubić Ćurčić, T. (2018), 'The EU enlargement and income convergence: Central and Eastern European countries vs. Western Balkan countries,' Entrepreneurial Business and Economics Review, vol. 6, no. 3, pp. 29-41. https://doi.org/10.15678/EBER.2018.060302

Szeles, M. R. \& Marinescu, N. (2010), 'Real convergence in the CEECs, euro area accession and the role of Romania,' The European Journal of Comparative Economics, vol. 7, no. 1, pp. 181-202.

Tsanana, E.; Katrakilidis, C. \& Pantelidis, P. (2013), 'Balkan area and EU-15: an empirical investigation of income convergence,' in Balkan and Eastern European Countries in the Midst of the Global Economic Crisis, Heidelberg: Physica, pp. 23-33. https://doi.org/10.1007/978-3-7908-2873-3_2

World Bank (2018), World Development Indicators Database. Retrieved from www. databank.worldbank.org [accessed 7 Dec 2018]

Yin, L.; Zestos, G. K. \& Michelis, L. (2003), 'Economic convergence in the European Union,' Journal of Economic Integration, vol. 18, no. 1, pp. 188-213. https://doi. org/10.11130/jei.2003.18.1.188

\section{Appendix 1: Multicollinearity tests}

\begin{tabular}{|c|c|c|c|}
\hline & Model 1 & Model 2 & Model 3 \\
\hline Variable/VIF & \multicolumn{3}{|c|}{} \\
\hline Log gdp pc & 1.00 & 1.00 & 1.00 \\
\hline Mean VIF & 1.00 & 1.00 & 1.00 \\
\hline
\end{tabular}

\begin{tabular}{|c|c|c|c|}
\hline & Model 4 & Model 5 & Model 6 \\
\hline \multicolumn{4}{|l|}{ Variable/VIF } \\
\hline Log gdp pc & 1.74 & 2.14 & 1.68 \\
\hline $\begin{array}{l}\text { Economic } \\
\text { openness }\end{array}$ & 1.11 & 1.12 & 1.10 \\
\hline Inflation rate & 1.42 & 1.89 & 1.60 \\
\hline $\begin{array}{l}\text { Gross fixed capital } \\
\text { formation }\end{array}$ & 1.36 & 1.36 & 1.68 \\
\hline Mean VIF & 1.41 & 1.63 & 1.41 \\
\hline
\end{tabular}




\begin{tabular}{|c|c|c|c|}
\hline & Model 7 & Model 8 & Model 9 \\
\hline Variable/VIF & 3.92 & 7.57 & 2.44 \\
\hline Log gdp pc & 1.54 & 1.31 & 1.33 \\
\hline $\begin{array}{c}\text { Economic } \\
\text { openness }\end{array}$ & 2.04 & 3.71 & 1.92 \\
\hline Inflation rate & 1.58 & 1.92 & 1.96 \\
\hline $\begin{array}{c}\text { Gross fixed capital } \\
\text { formation }\end{array}$ & 1.81 & 1.73 & 1.69 \\
\hline $\begin{array}{c}\text { General } \\
\text { government debt }\end{array}$ & 2.01 & 3.57 & 1.49 \\
\hline $\begin{array}{c}\text { Unemployment } \\
\text { rate }\end{array}$ & 1.69 & 1.80 & 1.47 \\
\hline $\begin{array}{c}\text { Population growth } \\
\text { rate }\end{array}$ & 2.08 & 3.09 & 1.76 \\
\hline Mean VIF & &
\end{tabular}

\begin{tabular}{|c|c|c|c|}
\hline & Model 10 & Model 11 & Model 12 \\
\hline Variable/VIF & \multicolumn{3}{|c|}{} \\
\hline Log gdp pc & 5.70 & 7.50 & 3.35 \\
\hline $\begin{array}{c}\text { Economic } \\
\text { openness }\end{array}$ & 1.54 & 1.30 & 1.34 \\
\hline Inflation rate & 2.78 & 3.43 & 1.84 \\
\hline $\begin{array}{c}\text { Gross fixed capital } \\
\text { formation }\end{array}$ & 1.84 & 1.88 & 1.47 \\
\hline $\begin{array}{c}\text { General } \\
\text { government debt }\end{array}$ & 1.84 & 1.69 & 1.75 \\
\hline $\begin{array}{c}\text { Unemployment } \\
\text { rate }\end{array}$ & 2.22 & 3.47 & 1.47 \\
\hline $\begin{array}{c}\text { Population growth } \\
\text { rate }\end{array}$ & 1.71 & 1.78 & 1.49 \\
\hline Mean VIF & 2.52 & 3.01 & 1.82 \\
\hline
\end{tabular}




\section{Appendix 2: ANOVA}

\section{Model 1}

\begin{tabular}{|c|c|c|c|}
\hline Source & SS & df & MS \\
\hline Model & 86.1992663 & 1 & 86.1992663 \\
\hline Residual & 61.5642846 & 38 & 1.62011275 \\
\hline Total & 147.763551 & 39 & 3.788809 \\
\hline
\end{tabular}

\section{Model 2}

\begin{tabular}{|c|c|c|c|}
\hline Source & SS & df & MS \\
\hline Model & 294.611427 & 1 & 294.611427 \\
\hline Residual & 273.756006 & 38 & 7.20410543 \\
\hline Total & 568.367433 & 39 & 14.5735239 \\
\hline
\end{tabular}

\section{Model 3}

\begin{tabular}{|c|c|c|c|}
\hline Source & SS & df & MS \\
\hline Model & 57.8265907 & 1 & 57.8265907 \\
\hline Residual & 103.334065 & 38 & 2.7193175 \\
\hline Total & 161.160656 & 39 & 4.13232451 \\
\hline
\end{tabular}

\section{Model 4}

\begin{tabular}{|c|c|c|c|}
\hline Source & SS & df & MS \\
\hline Model & 105.662135 & 4 & 26.4155338 \\
\hline Residual & 42.1014158 & 35 & 1.2028976 \\
\hline Total & 147.763551 & 39 & 3.788809 \\
\hline
\end{tabular}

\section{Model 5}

\begin{tabular}{|c|c|c|c|}
\hline Source & SS & df & MS \\
\hline Model & 388.978934 & 4 & 97.2447336 \\
\hline Residual & 179.388499 & 35 & 5.12538569 \\
\hline Total & 568.367433 & 39 & 14.5735239 \\
\hline
\end{tabular}




\section{Model 6}

\begin{tabular}{|c|c|c|c|}
\hline Source & SS & df & MS \\
\hline Model & 76.3817537 & 4 & 19.0954384 \\
\hline Residual & 84.7789021 & 35 & 2.42225435 \\
\hline Total & 161.160656 & 39 & 4.13232451 \\
\hline
\end{tabular}

\section{Model 7}

\begin{tabular}{|c|c|c|c|}
\hline Source & SS & df & MS \\
\hline Model & 114.974301 & 7 & 16.4249002 \\
\hline Residual & 32.7892494 & 32 & 1.02466404 \\
\hline Total & 147.763551 & 39 & 3.788809 \\
\hline
\end{tabular}

\section{Model 8}

\begin{tabular}{|c|c|c|c|}
\hline Source & SS & df & MS \\
\hline Model & 403.954594 & 7 & 57.7077991 \\
\hline Residual & 164.412839 & 32 & 5.13790123 \\
\hline Total & 568.367433 & 39 & 14.5735239 \\
\hline
\end{tabular}

\section{Model 9}

\begin{tabular}{|c|c|c|c|}
\hline Source & SS & df & MS \\
\hline Model & 87.6989516 & 7 & 12.5284217 \\
\hline Residual & 73.4617042 & 32 & 2.29567826 \\
\hline Total & 161.160656 & 39 & 4.13232451 \\
\hline
\end{tabular}

\section{Model 10}

\begin{tabular}{|c|c|c|c|}
\hline Source & SS & df & MS \\
\hline Model & 110.459671 & 7 & 15.779953 \\
\hline Residual & 32.3162537 & 31 & 1.0424598 \\
\hline Total & 142.775925 & 38 & 3.75726118 \\
\hline
\end{tabular}




\section{Model 11}

\begin{tabular}{|c|c|c|c|}
\hline Source & SS & df & MS \\
\hline Model & 372.879775 & 7 & 53.2685393 \\
\hline Residual & 163.909506 & 31 & 5.28740343 \\
\hline Total & 536.789281 & 38 & 14.1260337 \\
\hline
\end{tabular}

Model 12

\begin{tabular}{|c|c|c|c|}
\hline Source & SS & df & MS \\
\hline Model & 82.8507812 & 7 & 11.8358259 \\
\hline Residual & 67.9788349 & 31 & 2.19286564 \\
\hline Total & 150.829616 & 38 & 3.96920042 \\
\hline
\end{tabular}

